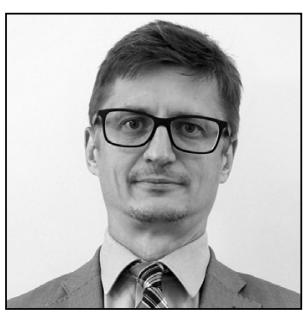

Ivo Pilving

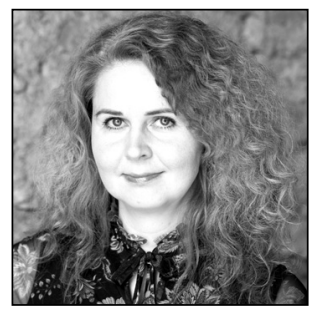

Monika Mikiver

Adviser to the Public Law Division Ministry of Justice

Doctoral student

University of Tartu
Supreme Court of Estonia

Associate Professor of Administrative Law University of Tartu

\title{
A Kratt as an Administrative Body: Algorithmic Decisions and Principles of Administrative Law
}

Artificial-intelligence applications used in the private sector, part of the 'fourth industrial revolution', are increasingly finding their way into public-sector offices. Estonia also has ambitions to use robots, or kratts $^{* *}$, more widely in public administration to support or replace officials. ${ }^{{ }^{*}}$ Public-sector kratts have received rather cursory academic attention, ${ }^{{ }^{2}}$ even though the legislator already granted authorisation in some fields (tax administration, environmental fees, unemployment insurance) for automated administrative decisions in 2019. ${ }^{*}$ There are plans to present the Riigikogu with a bill by June of 2020 that, if adopted, would introduce the necessary changes to existing legislation, including the Administrative Procedure Act, to allow for wider use of artificial intelligence. ${ }^{*} 4$

* This article presents the personal opinions of its authors and does not reflect the official position of any institution. We are thankful to Associate Professor of Machine Learning Meelis Kull (University of Tartu) and start-up entrepreneur Jaak Sarv (Geneto OÜ) for their consultation without passing any responsibility for the content of the article over to them.

** Translator's note: A kratt is a mythological, Estonian creature that comes to life to do its master's bidding when the devil is given three drops of blood. Today, it is also used as a metaphor for AI and its complexities. See also: https://en.wikipedia. org/wiki/Kratt.

1 Ministry of Economic Affairs and Communications, Eesti riiklik tehisintellekti alane tegevuskava 2019-2021 (Estonian National Action Plan on Artificial Intelligence 2019-2021). https://www.mkm.ee/sites/default/files/eesti_kratikava_juuli2019.pdf; State Chancellery / Ministry of Economic Affairs and Communications, Eesti tehisintellekti kasutuselevõtu ekspertrühma aruanne, 2019 (Report of the Expert Group on the Implementation of Artificial Intelligence in Estonia), p. 36. https://www. riigikantselei.ee/sites/default/files/riigikantselei/strateegiaburoo/eesti_tehisintellekti_kasutuselevotu_eksperdiruhma_aruanne.pdf; Kratt Project homepage. https://www.kratid.ee/.

2 K Lember, 'Tehisintellekti kasutamine haldusakti andmisel' (The Use of Artificial Intelligence in Administrative Acts) [2019] 10 Juridica 749; K Lember, Tehisintellekti kasutamine haldusakti andmisel (The Use of Artificial Intelligence in Administrative Acts) (Master, Tartu 2019).

3 Taxation Act, $\S 46^{2}$; Environmental Charges Act, § 336; Unemployment Insurance Act, § 23 (4). See also the Minister of Finance's Regulation 15, of 14. March 2019, and the Minister of the Environment's Regulation 34, of 20 June 2011.

4 'Eesti riiklik tehisintellekti alane tegevuskava' (Estonia's National Strategy for Artificial Intelligence) (2019-2021) 9. https:// www.mkm.ee/sites/default/files/eesti_kratikava_juuli2019.pdf. 
There has been talk in Estonian media about automating pension payments and unemployment registration. ${ }^{*}$ It is worth noting that not all e-government solutions are based on artificial intelligence and many are just simpler, automated forms of data processing. True, according to the principles of administrative law, if such human-guided solutions malfunction, they too may be transgressing the law. The real challenge, however, is legislating artificial intelligence, especially self-learning algorithms. With sloppy or malicious implementation, kratts may easily defy the rules of fair procedure, break the law, or treat individuals and businesses arbitrarily. Robots cannot explain their decisions yet. In order for our kratt project to succeed without exposing society and businesses to grave risks, the development of e-government must show full understanding of the nature of machine learning and, equally, its impact on administrative and judicial procedures. ${ }^{* 6}$ Acting rashly in this field is tantamount to exercising governmental authority in line with a horoscope. It would be naïve and dangerous to let ourselves get overcome by the illusion of a kratt that can or will soon be able to engage in reasoned debate or comprehend the content of human language, including legal texts. Proper implementation of the law requires both rationality and true understanding of the law. If the risks are perceived and considered and also the algorithms are used for the proper operations, there will be plenty of work for them in public administration and they could be beneficial to both efficiency and quality in decision-making.

To maintain focus in this article, we will not broach questions of data protection, ${ }^{*}{ }^{*}$ even though there is important commonality here when it comes to administrative law. We will consider algorithms without regard for whether decisions are made about humans or legal entities and whether these are based on personal or other data. The breadth of this article doesn't allow us to go into depth on the issue of equality. This article is aimed at giving the reader some examples of the use of robots in public administration (1); attempting to explain the technical nature of algorithmic administrative decisions (2); and, finally, examining the operation of the principles of Estonian administrative law in this type of decision-making (3). The main question posed by this article is whether and when a kratt can be taught to read and follow the law, as the legitimacy of governmental authority must not be sacrificed to progress.

\section{Algorithms in public administration}

Artificial-intelligence enthusiasts both in Estonia and abroad have pointed out that the implementation of algorithms affords wide opportunities for cost savings, productivity gains, and freeing officials from routine assignments. ${ }^{*}$ An increasingly powerful fleet of computers and ever more intelligent software can handle 'crazy' quantities of data and solve assignments that are too complicated for humans. The public sector has to keep up with the private sector. Among other applications, algorithms may become necessary in public administration to effectively control the use of artificial intelligence in business - in such areas as automated transactions on the stock exchange. ${ }^{*} 9$

Smart public administration systems can be classified as falling into the following categories: communication with people, ${ }^{*} 10$ internal activities, ${ }^{*} 11$ and preparation of decisions and decision-making. In the

5 M Mets, ‘Töötukassas hakkab sulle robot hüvitist määrama, kui sa töötuks jääd’ (A Robot Will Determine Your Unemployment Benefits If You Lose Your Job) Geenius (7 February 2019); 'Homme makstakse 79370 inimesele välja üksi elava pensionäri toetus' (Tomorrow, 79,370 Single Pensioner Benefits Will Be Paid) Maaleht (4 October 2018).

6 K Leetaru, 'A Reminder That Machine Learning Is about Correlations Not Causation' Forbes (15 January 2019). See also: 'Critical Approaches to Risk Assessment in Early Releases' Circuit Court Decision 1-09-14104.

7 See in particular: Regulation (EU) 2016/679 of the European Parliament and of the Council of 27 April 2016 on the protection of natural persons with regard to the processing of personal data and on the free movement of such data, and repealing Directive 95/46/EC (General Data Protection Regulation), art 22.

8 For example: C Coglianese and D Lehr, 'Regulating by Robot: Administrative Decision Making in the Machine-Learning Era' (2017) 105 Geo L.J. 1147, 1167 ff.

9 C Coglianese, 'Optimizing Regulation for an Optimizing Economy' (2018) 4 University of Pennsylvania Journal of Law and Public Affairs 1.

10 Chatbots have been tested around the world, for example, for taking testimony from border-crossers and asylum-seekers: J Stoklas, 'Bessere Grenzkontrollen durch Künstliche Intelligenz' 06363 Zeitschrift für Datenschutz (ZD-Aktuell 2018); 'About iBorderCtrl'. https://www.iborderctrl.eu/The-project; Harvard Ash Center for Democratic Governance and Innovation, 'Artificial Intelligence for Citizen Services and Government' (2017) 7; A Androutsopoulou et al., 'Transforming the Communication between Citizens and Government through AI-Guided Chatbots' (2019) 36 Government Information Quarterly 358. DOI: https://doi.org/10.1016/j.giq.2018.10.001. Cf. 'Statistikaameti kratt Iti aitab nii andmeesitajat kui ka statistika tarbijat' (About the Statistics Estonia Chatbot). https://www.kratid.ee/statistikaameti-kasutuslugu.

11 In Estonia, for example, the National Heritage Board plans to use kratt systems for museum inventory: https://www.muinsuskaitseamet.ee/et/uudised/kratt-salli-muudab-muuseumiinventuurid-kiiremaks-ja-mugavamaks. And elsewhere there has 
framework of this article, we are primarily interested in the latter two. In Estonia, for example, the Agricultural Registers and Information Board uses algorithms to analyse satellite imagery to check for compliance with grassland mowing obligations. The Tallinn City Government uses machine vision to measure traffic flows. The Ministry of the Interior wants to automate surveillance with a nationwide network of face- and number-recognition cameras. The Unemployment Insurance Fund hopes to implement artificial intelligence soon to assess the risk of unemployment. ${ }^{*} 12$

In the U.S., an algorithm determines family benefits and analyses the risks that may justify separating a child from his or her family. ${ }^{*}{ }^{3}$ They have also applied algorithms to bar entry into the United States, to approve pre-trial bail, to grant parole, in counter-terrorism, for planning inspection visits to restaurants, etc. There are predictions that artificial intelligence will soon be implemented in the fields of aeroplane pilots' licensing, tax refund assessment, and the assignment of detainees to prisons. ${ }^{*} 4$ Algorithmic predictive policing is used in the U.S. and also in Germany to predict the time, place, and perpetrator of an offence. The system analyses crime statistics together with camera and drone surveillance records to identify occurrence patterns for certain offences and uses the information gleaned to direct operational forces. Disputes over the use of algorithms have already reached the highest courts in European countries, such as the French and the Dutch Council of State, with regard to such issues as university applications and environmental permits. ${ }^{* 15}$

\section{Technical background}

\subsection{Basic concepts}

If we wish to understand artificial intelligence, we must first clarify some concepts from data science with definitions that are far from unanimous. ${ }^{*}{ }^{* 16}$ The latter notwithstanding, we will try to give one potential overview.

Artificial intelligence can be understood as the ability of a computer system to perform tasks commonly associated with the human mind, such as understanding and observing information, communicating, discussing, and learning. These features of artificial intelligence must be considered metaphors in the functional sense, because machine 'learning' is not actually the same as human learning. Artificial intelligence has many branches: automated decision support, speech recognition and synthesis, image recognition, and so on. A robot in our context is an artificial-intelligence application - an intelligent system. ${ }^{* 17}$

Data mining is the process of extracting new knowledge - generalisations, data correlation, and repeating patterns - from large volumes of data (big data) by using statistical methods. ${ }^{* 18}$ Various statistical

been hope expressed that artificial intelligence will begin to pre-sort and distribute applications and requests received by authorities: L Guggenberger, 'Einsatz künstlicher Intelligenz in der Verwaltung' [2019] NVwZ 844, 849.

12 'Kasutusjuhud' (Uses). https://www.kratid.ee/kasutuslood; Estonian Unemployment Insurance Fund, ‘Õlitatud masinavärk: Kuidas tehisintellekt kogu Töötukassa tegevust juhib?' (The Estonian Unemployment Insurance Fund, a Well-Oiled Machine: How Artificial Intelligence Runs All the Activities of the Unemployment Insurance Fund) Geenius (8 January 2020); 'Siseturvalisuse programmi 2020-2023 kavand kooskõlastamiseks' (Internal Security Programme 2020-2023 Draft for Approval) (14 November 2019). http://eelnoud.valitsus.ee/main/mount/docList/184b2e57-2c40-4e41-b5c2-e2e24ab71c30\#lb1Z2BiP.

13 S Valentine, 'Impoverished Algorithms: Misguided Governments, Flawed Technologies, and Social Control' (2019) 46 Fordham Urb. L. J. 364, 367.

14 E Berman, 'A Government of Law and Not of Machines' (2018) 98 Boston Univ. L. Rev 1290, 1320; C Coglianese and D Lehr (n 8) 1161; C Coglianese and D Lehr, 'Transparency and Algorithmic Governance' (2019) 71 Adm. L. Rev. 1, $6 f f$.

15 T Rademacher, 'Predictive Policing im deutschen Polizeirecht' (2017) 142 AöR 366. DOI: https://doi.org/10.1628/000389 117x15054009148798; L Guggenberger (n 11) 848-849; K Lember [2019] Juridica (n 2) 750-751; Conseil d'État 427916: Parcoursup.

16 See material from the Estonian data-science community: http://datasci.ee/post/2017/05/25/neli-sonakolksu-masinopetehisintellekt-suurandmed-andmeteadus/.

17 M Herberger, '„Künstliche Intelligenz“ und Recht' [2018] NJW 2826; H Surden, 'Machine Learning and Law' (2014) 89 Wash. L. Rev. 87, 89.

18 For example, if 2/3 of the owners of less-than-five-year-old Land Cruisers make less than 1,200 euros per month, in the context of national monitoring. U Lõhmus, Õigusriik ja inimese õigused (The Rule of Law and Human Rights) (Tartu 2018) 121. Cf. D Lehr and P Ohm, 'Playing with the Data: What Legal Scholars Should Learn about Machine Learning' (2017) 51 U. C. Davis L. Rev. 653, 672; L Guggenberger (n 11) 848. Data mining allows for, among other things, effective profile analysis (GDPR, art 4, para 4), but data mining may not be limited to the analysis of personal data. 
methods have previously allowed analysts to build mathematical models based on data sets to describe what is happening in nature or society. These can, in turn, help one assess and classify new situations and predict the future, such as the weather or criminal recidivism. This becomes particularly effective if the models are built on self-learning (machine-learning) algorithms. ${ }^{* 19}$

An algorithm is a set of precise mathematical or logical instructions, more generally a step-by-step procedure for solving a given problem (one example might be a cake recipe). The representation of an algorithm in programming language is a computer program. (1) Algorithms where the performance is entirely human-defined are distinguished from (2) algorithms that change their parameters autonomously in the course of learning. ${ }^{*}{ }^{* 20}$ The systems that automate the traditional decision-making processes in public administration (expert systems) are based on the former. Artificial-intelligence applications in public administration are mostly based on learning algorithms (sometimes also on more sophisticated non-learning algorithms).

Machine learning is the process by which an artificial-intelligence system improves its service by acquiring or reorganising new knowledge or skills. It is characterised by using the help of learning algorithms to assess situations or make predictions (e.g., making diagnoses, detecting credit card fraud, predicting crime). There are many machine-learning techniques, with different characteristics: linear and logistic regression, decision trees, the decision forest, artificial neural networks, etc. ${ }^{{ }^{21}}{ }^{2}$ In the most widespread - supervised learning - the algorithm is first trained from training data, a large number of data cases wherein the input (e.g., payment behaviour data) and output (e.g., solvency) values (features) are known. At a later stage, the application must calculate the output values for new cases on its own on the basis of the input data. These can be presented as numerical data (regression) or, for example, as yes/no answers (classification). The core element of a learning algorithm is its optimising or objective function. This is the mathematical expression of the algorithm's task, which contains a set of so-called weight parameters. ${ }^{* 2}$ As it learns, the robot looks for possible combinations of weights and chooses the working model that is most appropriate for the future and the one that gives solutions that deviate the least from the relationship given in the training data. These operations are repeated hundreds, thousands, or even millions of times. ${ }^{* 3}$

By automated administrative decisions we mean any administrative decision that is prepared or made by means of automation. This may be based on simpler or more sophisticated non-learning algorithms (expert systems) as well as on machine learning. ${ }^{* 24}$ For example, land-tax statements in Estonia are made entirely according to set rules and require no cleverness on the part of a computer. An algorithmic

19 E Berman (n 14) 1277, 1279-1280, 1284, 1286; W Hoffmann-Riem, 'Verhaltenssteuerung durch Algorithmen - Eine Herausforderung für das Recht' (2017) 142 AöR 1, 7-8. DOI: https://doi.org/10.1628/000389117x14894104852645; Gesellschaft für Informatik, Technische und rechtliche Betrachtungen algorithmischer Entscheidungsverfahren. Studien und Gutachten im Auftrag des Sachverständigenrats für Verbraucherfragen (Berlin: Sachverständigenrat für Verbraucherfragen 2018) 30. http://www.svr-verbraucherfragen.de/wp-content/uploads/GI_Studie_Algorithmenregulierung.pdf.

20 Among many others: M A Lemley and B Casey, 'Remedies for Robots' (2019) 86 Univ. of Chicago L. Rev. 1311, 1312. DOI: https://doi.org/10.2139/ssrn.3223621; M Finck, ‘Automated Decision-Making and Administrative Law' in P Cane et al. (eds), Oxford Handbook of Comparative Administrative Law (Oxford: Oxford University Press (2019) 2. https://papers. ssrn.com/sol3/papers.cfm?abstract_id=3433684.

21 Cf. M Koit and T Roosmaa, Tehisintellekt (Artificial Intelligence) (Tartu: Tartu Ülikool 2011) 194; material from the Estonian Data Science Community. http://datasci.ee/post/2017/05/25/neli-sonakolksu-masinope-tehisintellekt-suurandmedandmeteadus/; E Berman (n 14) 1279, 1284-1285; D Lehr and P Ohm (n 18) 671; Gesellschaft für Informatik (n 19) 30.

22 Instead of a manmade program, the 'decision rule' for an intelligent system is thus a mathematical probability mass function. See: T Wischmeyer, 'Regulierung intelligente Systeme' (2018) 143 AöR 1, 47 . A probability mass function indicates the probability that the (random) search value is equal to a certain value, such as getting a 6 when one rolls the dice: https:// en.wikipedia.org/wiki/Probability_mass_function. A generalisation of the formula for the simplest self-learning model - a linear regression - looks like this: $\hat{y}=w_{1} x_{1}+w_{2} x_{2}+\ldots w_{\mathrm{n}} x_{\mathrm{n}}$

In this equation, $y$ is the desired output variable, which is calculated on the basis of the input $x_{1}, \ldots, x_{n}$, taking into account the weight parameters $w_{1}, \ldots, w_{n}$ that are recalibrated during learning. With a linear regression, you can, for example, predict the value of real estate if you know the square metres, number of rooms, and distance from downtown. The actual mathematics of self-learning algorithms are more complex. They are based on multidimensional vectors and complex models that combine numerous regression equations. For example, in artificial neural networks, the structure of the equation mimics the neural connections in a human brain. Gesellschaft für Informatik (n 19) 31, 34.

23 Gesellschaft für Informatik (n 19); M A Lemley and B Casey (n 20) 1324-1325; C Coglianese and D Lehr (n 14) 15; T Wischmeyer (n 22) 12; D Lehr and P Ohm (n 18) 671; J Cobbe, 'Administrative Law and the Machines of Government: Judicial Review of Automated Public-Sector Decision-Making' (2019) 39 Legal Studies 636. DOI: https://doi.org/10.2139/ ssrn.3226913. In the case of unsupervised machine learning, output data is not used and the algorithm has to find the correlation in the data itself. A Berman (n 14) 1287.

24 Compare to: K Lember (Master, Tartu) (n 2) 13-14. 
administrative decision is more narrowly a decision made with the help of artificial intelligence. Automated administrative decisions can be divided into fully and semi-automated ones. The latter are approved by an official. Sometimes the computer decides, by following certain criteria provided, whether it is able to make a final decision, such as granting of a tax-refund claim, or an official must decide instead. ${ }^{{ }^{2} 2}$ Sometimes the concepts of automated and algorithmic decisions are used synonymously, and the two are often combined, but it must be taken into account that the learning potential of artificial intelligence brings both a new opportunity and also problems to public administration. ${ }^{* 26}$

\subsection{The basic characteristics of machine learning}

Self-learning algorithms can handle trillions of data cases, each with tens of thousands of variables. For some time, institutions in Estonia have been collecting data in large data warehouses for analytical purposes. ${ }^{* 27}$ Machine learning doesn't change the fundamental essence of data analysis but amplifies it: machine learning (in its current capacity) is only able to discover statistical correlations. These are not causal, natural, or legal relationships. Depending on the level of refinement of the model, the output data from machine learning may reflect the real world and anticipate the future with amazing accuracy. However, probability calculations will always retain some rate of error. ${ }^{{ }^{2} 8}$

Learning algorithms and models created during learning are so sizeable and complex that a human even an experienced computer scientist or the creator of the algorithm - may not always be able to observe or explain the work of a machine-learning application (this is opacity or the black-box effect). The more efficient the algorithm, the more opaque it is. Individual elements of a sophisticated machine-learning system, such as individual trees in a decision forest, can be tracked, but this does not allow much to be inferred about the process as a whole. Sometimes opacity of a system is actually desirable, to protect personal data or business secrets or to prevent the addressee of a decision from deceiving the algorithm. ${ }^{* 29}$

Because of the statistical nature of machine learning, very big sets of data are needed. Unfortunately, or, rather, fortunately, we have too little information on terrorist acts, for example, to make accurate estimates. ${ }^{*}{ }^{30}$ In addition to the quantity of data, high quality and standardisation are no less important: accuracy, relevance, organisation, compatibility, comprehensiveness, impartiality, and - above all - security. This applies to both the training data and the 'operating data' used in the actual implementation of the algorithm. All machine-learning predictions are based on training data and previous experience. Another golden rule of machine learning is this: garbage in, garbage out. Poor data quality can result in a variety of distortions, including failure to investigate all of the factors affecting assessment because of inability, not considering this important, or finding it economically nonessential. ${ }^{*}{ }^{31}$ At the same time, large numbers of decisions amplify the impact of an error rate in absolute terms.

25 See also: M Mets (n 5) on the Estonian Unemployment Insurance Fund decision.

26 A Guckelberger, Öffentliche Verwaltung im Zeitalter der Digitalisierung (Baden-Baden: Nomos 2019) 484ff. DOI: https:// doi.org/10.5771/9783748900535.

27 The data warehouse of the Police and Border Guard Board has been deemed a world-class system for analysis (https://issuu. com/ajakiri_radar/docs/radar_19/14). For more on the Unemployment Insurance Fund warehouse, see: 'Maksuamet ühise IT-süsteemiga rahul' (Unemployment Fund Happy with Joint IT System) Äripäev (9 May 2003).

28 W Hoffmann-Riem, 'Rechtliche Rahmenbedingungen für und regulative Herausforderungen durch Big Data' in W Hoffmann-Riem (ed), Big Data - Regulative Herausforderungen (Baden-Baden: Nomos 2018) 20. DOI: https://doi. org/10.5771/9783845290393-9; W Hoffmann-Riem (n 19) 13; M Finck (n 20) 2, 11; T Wischmeyer (n 22) 10, 13-14 (incl. cit. 48), 17-18, 24; C Coglianese and D Lehr (n 8) 1156-1159.

29 A Deeks, 'The Judicial Demand for Explainable Artificial Intelligence' (2019) 199 Columbia L. Rev. 1829, 1834; M Finck (n 20) 9; C Coglianese and D Lehr (n 14) 17; J Burrell, 'How the Machine "Thinks": Understanding Opacity in Machine Learning Algorithms' (2016) 3 Big Data \& Society 3; J Tomlinson, K Sheridan, and A Harkens, 'Proving Public Law Error in Automated Decision-Making Systems' (2019) 10. DOI: https://doi.org/10.2139/ssrn.3476657. For example, the Sharemind technology was developed in Estonia for the secure analysis of personal data - i.e., to enhance the black-box effect. D Bogdanov, Sharemind: Programmable Secure Computations with Practical Applications (Tartu Ülikooli Kirjastus 2013).

30 D Lehr and P Ohm (n 18) 678; T Wischmeyer (n 22) 16, 33.

31 'Tehisintellekti ekspertrühma aruanne' (Report of the Artificial Intelligence Expert Group) (n 1) 19; C Coglianese and D Lehr (n 8) 1157; D Lehr and P Ohm (n 18) 681; E Berman (n 14) 1302;. C Weyerer and P F Langer, 'Garbage In, Garbage Out: The Vicious Cycle of AI-Based Discrimination in the Public Sector' in Proceedings of the 20th Annual International Conference on Digital Government Research (2019) 509 ff. DOI: https://doi.org/10.1145/3325112.3328220. 
Models developed and decisions made through machine learning cannot be completely foreseen or guided. ${ }^{*}{ }^{2}$ Nonetheless, people - programmers; analysts; data scientists; system developers; and, ultimately, the end user - have a huge role and responsibility in the quality of machine learning's outcomes. The end result is influenced by all kinds of strategic decisions and fine-tuning: defining the relevant output value (target features), ${ }^{*} 33$ creating an objective function, selecting and developing the type of algorithm, fine-tuning the algorithm to be more cautious or bolder, and performing testing and auditing. We must take into account that two distinct types of algorithms, both of which might be very precise on their own, may give completely different answers for the same case. ${ }^{*} 34$

\section{Rule of robots or smart rule of law?}

The above-mentioned technicalities of machine learning pose significant legal challenges in public administration. Machine learning can produce great results statistically, but in certain cases, a lot can go wrong also.

\subsection{Administrative risks: Digital delegation and privatisation}

The authority of the government can only be exercised by a competent institution. This institution may use automatic devices, such as a traffic light or computer, for this purpose. The more discretion is given to the algorithm, the more acute becomes the question of whether the decision is actually subject to the control of the competent institution or, instead, it is running its own course. ${ }^{*} 35$ In our view, the decision is always formally attributed to the institution using the algorithm and they remain legally responsible for it. But with larger decisions to be made, a substantive problem actually arises: can the institution make the algorithm sufficiently consider all the important details of a decision? ${ }^{*} 36$

We can assume that the state will have a practical need to delegate the development of its algorithms largely to privately held IT companies. That makes it important that we not lose democratic control over the companies directly managing the algorithm, as with making sure they don't gain full control over the content of administrative decisions or maximise their profits at the expense of the quality of the administrative decisions. Therefore, as we develop our e-government, we have to analyse whether the current public procurement and administrative co-operation laws sufficiently address these risks. ${ }^{*} 37$

\subsection{Impartiality}

For decades, people have been hoping that artificial intelligence can help create a bias-free, selfless, comfort-zone-free decision-maker that treats everyone equally. Regrettably, the reality of machine learning has shown some serious difficulties with the problem of bias. Artificial intelligence tends to discriminate against some groups of people when the quality of input data or the algorithm itself is inadequate. For example, when some groups have been monitored more closely than others, this may become reflected in the training data (as seen with blacks in predictive policing in the U.S. or in recidivism assessment systems). ${ }^{*} 38$

32 C Coglianese and D Lehr (n 8) 1167.

33 For example, in predicting recidivism, we are interested in the likelihood of a new crime occurring in three, five, or ten years, or we might want to know which variable should be used to measure the best candidate for office in a public competition.

34 E Berman (n 14) 1305, 1325 ff; D Lehr and P Ohm (n 18), 669 ff; J Burrell (n 29 ) 7.

35 C Coglianese and D Lehr (n 14), 32 ff.

36 See Subsection 3.5 for more on these risks; cf. M Schröder, 'Rahmenbedingungen der Digitalisierung der Verwaltung' (2019) 110 Verwaltungsarchiv 328, 347.

37 W Hoffmann-Riem (n 19) 24-25; A Guckelberger (n 26) 410; C Krönke, 'Vergaberecht als Digitalisierungsfolgenrecht. Zugleich ein Beitrag zur Theorie des Vergaberechts' (2019) 52 Die Verwaltung 65; M Finck (n 20) 10.

38 E Berman (n 14) 1326; T Wischmeyer (n 22) 26 ff; M Finck (n 20) 11; L Guggenberger (n 11) 847; H Steege, 'Algorithmenbasierte Diskriminierung durch Einsatz von Künstlicher Intelligenz' [2019] MultiMedia und Recht 716. 


\subsection{Legal basis}

The Estonian Constitution's §3 (1) 1 states that governmental authority shall be exercised solely pursuant to the law. The question of when and how the legislature should authorise institutions to implement machinelearning technology cannot be answered simply or unilaterally. If machine learning is used only in the preparation of administrative decisions (e.g., to forecast pollutant emissions before issuing of an environmental permit) while the final administrative decision is made by a human official following normal procedural rules, then machine learning can be considered one detail of the administrative procedure and control over the decision-making remains at the discretion of the administrative institution (Administrative Procedure Act $\$ 5$ (1)), hence not requiring any special provisions. ${ }^{*} 39$ If the role of the human in decision-making is limited to that of a rubber stamp or disappears altogether, then it may be a matter requiring parliamentary approval. In each area (licences, social benefits, environmental protection, law enforcement, immigration, etc.), the widespread implementation of intelligent systems raises specific issues that need to be resolved separately and balanced with appropriate substantive and procedural guarantees. ${ }^{*} 40$ Aside from the legal issues, it would be wise to consider the risks to public finance: does it make the legislature a slave to the robot? An expensive and complicated implementation system may start to obstruct legislative changes and political will. ${ }^{*} 4$

The Taxation Act's $\$ 46^{2}$ (1) grants an implementing institution broad powers to make automatic administrative decisions in the field of taxation without intervention by an official. A more detailed list must be established by the Ministry of Finance. ${ }^{*} 2$ The law does not impose restrictions on the type or manner of decisions that may be automated. Because of its rather precise legal definitions, taxation is considered rather suitable for automation. Here, well-founded reliance on a broad mandate shouldn't produce unacceptable results. However, granting total power to an authority ${ }^{*} 43$ to fully automate any administrative decision may result in violations of $\S 3$ (1) and $\S 14$ of the Constitution.

\subsection{Supremacy of the law}

Pursuant to $\S 3$ (1) 1 of the Constitution, the exercise of governmental authority may be guided by an algorithm only if the word of the law is followed at all times during its application. ${ }^{*} 4$ But this requires the human or self-learning system to convert the law into an algorithm. In some cases, this may be possible in principle, albeit a substantial task, but that would require the developer to have very in-depth knowledge of information technology, mathematics, and the law. ${ }^{*} 5$ Still, many legal provisions cannot be described in the unambiguous variables specific to an algorithm. ${ }^{*} 6$ This is due both to the inevitable vagueness of the instrument of law - human language - and to the intentional slack that ensures flexibility in legislation. ${ }^{*} 7$ Instead of step-by-step instructions (conditional programs), the law often uses outcome-oriented

39 Cf. M Schröder (n 36) 343. The same goes for Australia: M Finck (n 20) 18.

40 T Wischmeyer ( $n$ 22) 7-8, 41. Article 22 of the GDPR also allows fully automated decisions in processing of personal data only as an exception - for the purposes of fulfilling a contract, in cases stipulated by the law, or with the person's consent.

41 An example is the SKAIS2 information system saga of the Social Insurance Board. See: https://www.err.ee/613092/skais2projekti-labikukkumise-kronoloogia.

42 Legislation with a much narrower scope includes: Estonia’s Environmental Charges Act $\S 33^{6}$ (1, 3), and Unemployment Insurance Act $\S 23$ (4). See also Note 63, below, with regard to discretionary authority.

43 Compare to the proposed supplement to the Administrative Procedure Act, $\S 5^{1}$ (1): 'An administrative institution may issue an administrative act or document automatically, without any direct intervention by a person acting on behalf of the administrative institution (henceforth: automated administrative act and document).' T Kerikmäe et al., Identifying and Proposing Solutions to the Regulatory Issues Needed to Address the Use of Autonomous Intelligent Technologies, Phase III Report (2019) 6-7.

44 Bundesministerium des Inneren, 'Automatisiert erlassene Verwaltungsakte und Bekanntgabe über Internetplattformen Fortentwicklung des Verfahrensrechts im Zeichen der Digitalisierung: Wie können rechtsstaatliche Standards gewahrt werden?' [2015] NVwZ 1114, 1116-1117.

45 Because of their precision, most traffic laws can probably be taught to self-driving cars, but there are also dilemmas that come up in traffic that do not have a determinate answer. See also: M A Lemley and B Casey (n 20) 1311, 1329 ff. It is also difficult to teach a machine to make exceptions to rules, such as driving through a red light. Ibid, 1349.

46 E Berman (n 14) 1329; A Guckelberger (n 26) 367-370. Compare to: M Maksing, Kohtupraktika ühtlustamise võimalustest infotehnoloogiliste lahenduste abil (The Possibilities for Harmonizing Case Law Using IT Solutions) (Master, Tartu Ülikool 2017) 25.

47 L Reisberg, Semiotic Model for the Interpretation of Undefined Legal Concepts and Filling Legal Gaps (Tartu: Tartu Ülikooli Kirjastus 2019) 170-173; K Larenz and C-W Canaris, Methodenlehre der Rechtswissenschaft (Berlin: Springer 1995) 26; 
programs: ${ }^{*} 48$ general objectives such as better living environments, public involvement and informing the public, balancing and integration of interests, sufficiency of information, expedient and economical while also reasonable land use (Planning Act $\S \S 8-12$ ); discretionary powers, such as the right of a lawenforcement agency to issue a precept to a person liable for public order to counter a threat or eliminate a disturbance (Law Enforcement Act §28); undefined legal terms, such as overriding public interest (Water Act §192 (2)) or danger (Law Enforcement Act §5 (2)); and general principles, such as human dignity, proportionality, and equal treatment (Constitution §10, §11 sentence 2, and §12).

By dint of the uncertainty of the law, legal subsumptions ${ }^{*} 49$ (such as the decisions necessary to implement a law - is an object a building in the sense of the Building Act, is a person a contracting entity in the sense of the Public Procurement Act, is the recipient of rural support sustainable, and how should one define a goods market in competition supervision?) are not mere formal logical acts but require judgement. Before a situation is resolved, the decision-maker must interpret the norm to explain whether the legislator wanted to subject the situation to the norm or not. What's more, the decision must be made in situations that didn't occur to the legislature, such as that of a new cross-border tax avoidance scheme. Here, it is up to the implementer to assess whether he or she is dealing with permissible optimisation or abuse (Taxation Act §84). Those implementing the law - the ministers, officials, judges, and contracting parties - continue to interpret it and fill in the gaps in the regulatory process started by the parliament. It is up to them to make the law concrete. ${ }^{*} 50$

We must note that there is some similarity to machine learning here: a learning algorithm is not yet complete in the form in which humans created it. It keeps developing itself and is able to create new models to classify situations. So couldn't the legislator's real will not be modelled in this way as well? Is it not a standard classification task for a smart system, almost like finding cat pictures? Regrettably, the source material for machine learning - data from the past - cannot in principle be sufficient for further developing the law as code. ${ }^{*}{ }^{1} \mathrm{~A}$ law's enforcer must also account for existing judicial and administrative practice ${ }^{*}{ }^{52}$ and the generalisations that crystallise out of it, but his or her sources must not be limited to this alone. ${ }^{*} 53 \mathrm{An}$ official or a judge must be able to perceive, understand, and apply a much broader context: the history of the law, the systematics of norms, the objective of this law, and the general meaning of justice but especially the direct and indirect effects of the decision. It is not possible in all fields to produce sufficient quantitative or qualitative data to describe all the layers of law and its operating environment. And it is far from possible for (current) smart systems to follow all of this material in real time. Therefore, many situations require a rational being who understands the peculiarities of the specific situations being regulated and, when necessary, creates a new law appropriate for the situation instead of searching for one in previously tested patterns. ${ }^{*} 4$

The vagueness of legal concepts expressed in natural language is not a flaw in the law. It must remain possible to argue over the law if we are to reach fair decisions in specific situations. But this requires open and honest discussion over different interpretations and ways of assessing the facts. Even if you translate the law into zeroes and ones, you don't escape the need to interpret it. This need would simply move from the decision-making stage to (1) the expert system's creation and calibration stage or (2) the intelligent system's learning stage. ${ }^{*} 55$ In both cases, at least the persons concerned and presumably also the competent adminis-

K N Kotsoglou, 'Subsumtionsautomat 2.0: Über die (Un-)Möglichkeit einer Algorithmisierung der Rechtserzeugung' [2014] JZ 451, 452-454. DOI: https://doi.org/10.1628/002268814x13940152210984; R Narits, Ôiguse entsüklopeedia (Tallinn: Tartu Ülikool 1995) 68 ff; R Narits, Õigusteaduse metodoloogia I (Tallinn 1997) 84 ff.

48 See more on this distinction: N Luhmann, Das Recht der Gesellschaft (Frankfurt am Main: Suhrkamp 2018) 195ff.

49 A decision on whether the vital aspects of a case meet the presumptive preconditions for application stipulated by a norm. R Narits, Õiguse entsüklopeedia (Encyclopaedia of Law) (Tallinn: Tartu Ülikool 1995) 73.

50 In the example of the general requirements for agricultural animals according to Decision of the Administrative Law Chamber of the Supreme Court 3-15-443/54, para 12.

51 Cf. C Coglianese and D Lehr (n 14) 14; E Berman (n 14) 1351; K N Kotsoglou (n 47) 453; M Herberger (n 17) 2829.

52 Moreover, it must be noted that even if someone were able to convert all jurisprudence into algorithmic learning data, said data must also first be interpreted, because judgements are written in natural language.

53 This would be acceptable from the standpoint of legal certainty but unacceptable from a fairness standpoint; compare to: A Kaufmann, Rechtsphilosophie (Munich: Beck 1997) 122.

54 E Berman (n 14) 1315; cf. F Pasquale, 'A Rule of Persons, Not Machines: The Limits of Legal Automation' (2019) 87 G. Washington L. Rev. 1, 48. Cf. A Adrian, 'Der Richterautomat ist möglich - Semantik ist nur eine Illusion' (2017) 48 Rechtstheorie 77, 87. DOI: https://doi.org/10.3790/rth.48.1.77; P Enders, 'Einsatz künstlicher Intelligenz bei juristischer Entscheidungsfindung' [2018] JA 721, 726.

55 E Berman (n 14) 1331. In the natural-language processing systems already being tested in Axel Adrian's lab that are capable of finding statistical correlations between court judgements and scientific articles or other legal 'language-equivalent' texts (n 54) $188 f f$. In our view, this is not enough for a rational application of the law. 
trative institution (considering the complexity of machine learning) lack an effective opportunity to have a say in the interpretation. Because of their complexity, the decisions made by a self-learning algorithm are not just difficult to predict, they are structurally unpredictable. ${ }^{*} 6$ But how can you ensure that the algorithm won't deviate from the law as it learns? Periodic testing and auditing is not a sufficient solution, because tests are also unable to anticipate or run through all of life's possible scenarios. The costs of such extensive calibration and testing would eventually outweigh the benefits. ${ }^{*}{ }^{*}$ Also, the machine-language translation of a law that an administrative robot could supposedly follow is anything but static. It is corrected not only by new laws, interpretations in case $\operatorname{law}^{*}{ }^{* 8}$, and decisions made in constitutional review but also by the development of the context of the law - society. Weak artificial intelligence is not capable of perceiving or applying these changes itself.

The main question here is not whether and to what extent a machine makes mistakes. A machine doesn't perform any legal-thought operations. In the best case and only with sufficient quantities of data, machine learning (in its current capacity) can merely mimic legal decisions through statistical operations, not comprehend the content of the law or make rational decisions based on it. ${ }^{*} 59$ But that is precisely the demand set by \$3 (1) 1 of the Constitution. We are claiming not that an expert or smart system is unable to replace any legal assessment, just that solutions to the problems described above must be found when one is using such systems.

\subsection{Discretionary power}

These problems are exacerbated by discretionary decisions where the law does not prescribe clear instructions, such as those on whether to require the demolition of a building, what requirements to set for service providers in a procurement, whether and under what conditions to allow extraction in an area with groundwater problems, or where to build a landfill. Ostensibly, discretionary power does not give authorities the right to make arbitrary decisions. Discretionary decisions must also obey the general principles of justice and consider the purpose of the law and all of the relevant facts specific to each individual case (Administrative Procedure Act $\$ 4(2)) .{ }^{*} 60$ An algorithm that has been completely defined by humans is not suited to making discretionary decisions, because circumstances are unpredictable. True, there is some measure of standardisation and generalisation in making judgements, as in the case of internal administrative rules, but officials must retain the right and the duty to deviate from such standards when it comes to atypical cases. ${ }^{* 1}$ However, optimists believe that, even though the capability is lacking at the moment, it is not rigid algorithms but machine learning that will be able to take advantage of the dynamic discretionary parameters to soon work within the lines of value principles and discretionary bounds. ${ }^{* 62}$

This does not seem realistic for the near future. ${ }^{* 63}$ First of all, decisions of this kind are too unique for generation of large enough bodies of data for machine learning to be capable of modelling them. Secondly, discretionary rules and the general principles of justice may seem like simple maxims at first glance. They may even be represented as mathematical formulas, but this does not yet guarantee their practical applicability to machine learning. Let us illustrate with R. Alexy's proportionality formula by trying to explain its application through the example of an injunction to shut down a fish-processing plant infected with a dangerous bacterium.

56 T Wischmeyer (n 22) 334.

57 E Berman (n 14) 1338.

58 Kaalutlusõiguse kontekstis (The Context of Discretionary Law); K Lember (Master, Tartu) (n 2) 53.

59 A computer processes legal texts as data, not as information; see: K N Kotsoglou [2014] JZ. Axel Adrian argues that humans also merely pretend to understand the meaning of natural language and semantics are merely an illusion, which means that replacing the human with another computer does not pose fundamental problems (n 54) 91. The scope of this article does not allow us to analyse these philosophical claims. We assume that humans are conscious and capable of understanding sentences, including legal provisions, in natural language and that they can associate these with their own consciousness.

60 See also: K Merusk and I Pilving, Halduskohtumenetluse seadustik. Kommenteeritud väljaanne (Code of Administrative Court Procedure, Annotated Edition) (Tallinn: Juura 2013) § 158, comment F.

61 Decision of the Administrative Law Chamber of the Supreme Court 3-3-1-72-13, para 21; 3-3-1-81-07, paras 13-14. Cf. M Schröder (n 36) 333; A Guckelberger (n 26) 373.

62 See also: L Guggenberger's sources (n 11) 848.

63 When writing $\S 46^{2}$ of the Taxation Act, its authors did not consider it possible to use automated administrative acts in the case of discretion. Explanatory report to the Taxation Act amendments and other laws (675 SE) 36. The text of the law, however, does not mention this restriction. 


$$
W i, j=\frac{I_{i} \cdot W_{i} \cdot R_{i}}{I_{j} \cdot W_{j} \cdot R_{j}}
$$

Here, $i$ and $j$ are the principles considered in making the decision (in this case, fundamental rights: consumer health versus the freedom to conduct business). $W_{i, j}$ is the specific value of principle $i$ in relation to principle $j$. For the Veterinary and Food Board to issue an injunction, $i$, or health, must outweigh $j$, or freedom to conduct business. In other words, $W_{i, j}$ must be $>1$. $I$ is the intensity of interference with the given principle, which expresses the extent of potential damage if one or the other principle recedes (consumer illness or death / the facility's bankruptcy and unemployment for its many workers). $W$ is the relevant principle's abstract value and illustrates the general importance we attach to public health and to freedom to conduct business. $R$ is the probability of damage that could result from violation of the principle (for example, if the plant stays open, the product will not necessarily be contaminated but might be, but if it is shut down, bankruptcy is certain). ${ }^{*} 64$

Even if we disregard other criticism of this equation, ${ }^{* 65}$ the real difficulty does not lie in calculations so much as in assigning correct values to the variables in the equation and in arguments over whether and to what extent one or another principle (fundamental right) is infringed, what the proven facts are, and whether they are even relevant with regard to the judgement to be made. The likelihood of one or another outcome $(R)$ may depend on very special circumstances that did not occur to those inputting the algorithm's learning and working data; however, judgements made on the importance of the principles $(W)$ and the intensity of interference $(I)$ are value-based and can only be made in acute awareness of the sizeable context accumulated over a long span of evolution in law and society. If this information is not easily accessible to the human official, the deficiency can be overcome by communication between the decision-maker and the parties to the proceeding in a fair administrative procedure (see Subsection 3.6, below). The weak machine-learning technologies available today and expected in the near future are characterised by limited understanding of the context and the content of communication. ${ }^{* 66}$ This is equally true for undefined legal concepts (public interest, material harm, etc.). ${ }^{* 67}$ Even if, for example, the Law Enforcement Act's \$5 (2) defines a threat as a sufficiently probable offence (e.g., food poisoning), it still does not quantify the level of sufficient probability. This is a legal judgement that is based on value judgements as to the significance of one or another interest, not just a statistical prognosis of the occurrence of damage.

To fully delegate a complex discretionary or judgement-based decision to an algorithm would, in our opinion, constitute a gross breach of discretion, against the Code of Administrative Court Procedure's $\S 158$ (3) 1 (failure of an administrative institution to exercise discretionary power). An algorithm can, however, be implemented as an aid.

\subsection{Fair proceedings and the principle of investigation}

Fair proceedings - especially the right to a hearing (Administrative Procedure $\$ 40$ (1)) - play an important role in guaranteeing the substance of a decision as well as the dignity of the persons concerned. ${ }^{* 68}$ The establishment and further development of law in a state based on the rule of law must take place in the

64 See: R Alexy, 'Constitutional Rights, Proportionality, and Argumentation' (public lecture at the University of Tartu, 10 December 2019). https://www.uttv.ee/naita?id=29148; T Mori, 'Wirkt in der Abwägung wirklich das formelle Prinzip? Eine Kritik an der Deutung verfassungsgerichtlicher Entscheidungen durch Robert Alexy' (2019) 58 Der Staat 555, 561. DOI: https://doi.org/10.3790/staa.58.4.555.

65 T Mori (ibid), for example, gives examples of case law wherein this formula isn't applicable, on page 562.

66 Cf. C Coglianese and D Lehr (n 8) 1218; J Cobbe, 'Administrative Law and the Machines of Government: Judicial Review of Automated Public-Sector Decision-Making' (2018). DOI: https://doi.org/10.2139/ssrn.3226913; A von Graevenitz, ',Zwei mal Zwei ist Grün“ - Mensch und KI im Vergleich' [2018] ZRP 238, 240. See also: Ü Madise, 'Põhiseaduse vaimust ja võimust muutuvas ühiskonnas' (The Spirit and Power of the Constitution in a Changing Society) in T Soomre (ed), Teadusmõte Eestis IX (Legal Thought in Estonia) (Teadus ja ühiskond 2018) 138. On value judgements: R Narits, 'Eesti õiguskord ja väärtusjurisprudents' (Estonian Legal Order and Value Jurisprudence) [1998] 1 Juridica 2.

67 See also: A Guckelberger (n 26) 389 ff; T Wischmeyer (n 22) 17-18. Cf. A Berger, 'Der automatisierte Verwaltungsakt' [2018] NVwZ 1260, 1263.

68 On this, see examples: E Andresen and V Olle's piece in J Sootak (ed), Õigus igaühele (Law for Everyone) (Juura: Tallinn 2014) 149-150; I Pilving's contribution to A Aedmaa et al., Haldusmenetluse käsiraamat (Handbook of Administrative Process) (Tartu: Tartu Ülikooli Kirjastus 2004), 215 ff. On automated processing of personal data, see: GDPR recital 71, para 1. 
framework of honest and open (at least to the persons concerned) dialogue. In decisions affecting large numbers of people, such as spatial planning and environmental permits, the right to express an opinion must also be open to the public. Such discussions are merely mimicked by contemporary algorithms (i.e., debate robots), not actually (meaningfully) held. In the case of machine learning, listening to the discussion would be all the more necessary, as the algorithm may not be programmed or have learned to account for unpredictable circumstances. A rare event may turn out to be decisive for the right prediction, as with a broken leg meaning that a person won't complete his weekly workout even if years of his behavioural patterns would indicate otherwise. ${ }^{*} 69$

C. Coglianes and D. Lehr point out that the right to a hearing is fairly flexible under U.S. law and that machine learning without a hearing could, in some situations, yield more accurate decisions on average than humans through the hearing process. ${ }^{*}{ }^{* 0}$ This is not adequate justification. A citizen or business falling within the margin of error does not have to be satisfied with pretty statistics and retains the right to demand a lawful decision on his case. In Estonia, the Administrative Procedure Act’s \$40 (3) provides several exceptions to the right to a hearing. The catalogue of exceptions may be augmented via special laws if the effectiveness of a hearing is low in practice. But no general exception to any administrative acts on algorithms may be granted. The greater the discretion of the authority, the more necessary communication becomes for the proceedings, and, therefore, the less possibility there is of using fully automated decisions; i.e., when artificial intelligence is applied, the person concerned must retain the opportunity to interact with an official. ${ }^{*}{ }^{*}$

The effective protection of rights and public interest is guided by the principle of investigation in the Administrative Procedure Act (\$6) - an administrative institution is obligated to take initiative in investigating all relevant facts. This is also a challenge for algorithms, because they cannot deal with circumstances that haven't been entered in their systems. The reality around us is not yet completely digitised or machine-readable with sensors. Therefore, a machine can only consider fragments of the actual situation in its analysis. ${ }^{* 72}$ But a human is able to take initiative in searching for additional data from sources that have not been provided or are not in some manual. Not knowing important information does not exonerate the decision-maker who errs against a prohibitive norm. ${ }^{*} 73$ This is why German law requires the intervention of a human officer, obliging him or her to manually correct an automated decision in light of the additional circumstances. ${ }^{*} 74$ However, with intelligent implementation, machine learning can be applied to follow the principle of investigation - e.g., to select tax returns that need more extensive, manual control. ${ }^{*} 75$

\subsection{Reasoning}

The reasoning behind decisions made by governmental authorities is a core element of a fair procedure. According to $\$ 56$ of the Administrative Procedure Act, an administrative act must state its legal and factual basis (the provision delegating authority and the circumstances justifying its application) and, if the act is based on discretion, at least the primary motives for the choice between the options (e.g., why the pulp mill should be in Narva and not Tartu or why the construction of a wind farm should be prohibited). This is not a mere ethical recommendation but a fundamental, constitutional obligation. ${ }^{*}{ }^{76} \mathrm{~A}$ law-enforcement mandate

69 E Berman (n 14) 1323; A Guckelberger (n 26) 396.

70 C Coglianese and D Lehr (n 8) 1186.

71 The same is seen on page 36 of: 675 SE Explanatory Report (n 63). See also: Decision of the Administrative Law Chamber of the Supreme Court 3-3-1-76-12, 14, on disciplinary action.

72 T Rademacher (n 15) 383; A Adrian (n 54) 77, 86.

73 Concerning prohibitions on procurement agreements, see: Decision of the Administrative Law Chamber of the Supreme Court 3-3-1-7-17, para 11. In the case of discretion, ignorance can be an excuse if the person had the opportunity to inform the authority of it. With regard to deportation, see: Decision of the Administrative Law Chamber of the Supreme Court 3-181891/46, 19.

74 See: Verwaltungsfahrensgesetz (VwVfG) s 24 (1). In relation to this, see also: F Kopp and U Ramsauer, Verwaltungsverfahrensgesetz. Kommentar (Munich: Beck 2019) § 24 Rn 8; L Guggenberger (n 11) 847.

75 M Belkin, 'Maksuamet hakkab tehisintellekti abiga ümbrikupalga maksjaid püüdma' (The Taxation Board Will Use Artificial Intelligence To Find Envelope Wages) Geenius (6 January 2020).

76 The obligation of reasoning is found in the Constitution $\S 13(2 \mathrm{ff})$ and $\S 15(1) 1 \mathrm{ff}$, as well as in the Charter of Fundamental Rights of the European Union art 41. For more, see: N Parrest in A Aedmaa et al. (n 68) 299 ff. Above all else, in the event of total opacity, wider public support for machine decisions is unlikely as this rather evokes suspicions of manipulation or even of a 'deep state’. See: M Herberger (n 17) 2828. 
shall only be granted to an entity that can demonstrate that their decision is lawful - in accordance with external limits as well as internal rules of discretion. This brings us to an important difference between the private and public sectors: the exercise of freedoms does not need to be justified, but the use of authority does. A person receiving a notice of tax assessment or a demolition injunction does not have to accept an official's claim that 'I don't know why, but the machine made this decision about you'.

Neither Administrative Procedure Act $\$ 56$ nor Taxation Act $\$ 46^{2}$ articulates exemptions for automatic, including algorithmic, administrative decisions. Such exceptions would violate the Constitution as well as generally accepted standards in democratic, rule-of-law states. ${ }^{*} 77$ As we have seen, creators of algorithms are often unable to explain the decisions made by a robot, for reason of machine learning's opacity. In the U.S., Houston used an algorithmic decision-making process to terminate employment contracts with teachers in 2011. During the ensuing litigation, the school administrator was unable to explain the functioning of the algorithm, claiming that he had no ownership or control over the technology. ${ }^{*}{ }^{8}$ Also, the U.S. Government has cited the issue of opacity as a matter of concern. ${ }^{*} 79$

Some experts see a possibility of solving the problem of opacity by using artificial intelligence to develop language-processing programs enough that the computer can analyse numerous prior justifications to synthesise a machine argument that is seemingly similar to legal arguments. ${ }^{*}{ }^{*}$ This method would still use only statistics, not reasoning based on the methods of jurisprudence, meaning that it could only offer an inadmissible semblance. Reasoning must be genuine, though. ${ }^{*} 81$ There is a growing search for ways to increase transparency in machine learning by following the principles of accountability and explainability. Among other things, this requires greater access to learning and source data, the data processing, and the algorithms and their learning processes. ${ }^{*} 82$ These challenges entail collisions with business secrets, internal information, personal data protection, and - above all - a human's ability to analyse the work of an algorithm. Moreover, the most important aspect of the reasoning for an administrative act is not its technical description of how the decision was made but the motives behind it, why the decision made was this particular one. Even in the case of decisions made by humans, we are interested not in the biochemical details of the decision-maker's brain but in his or her explanations. There is little benefit to expanding the overall transparency of machine learning to the reasoning of individual cases. ${ }^{*} 3$

As an alternative, development has started on so-called explainable artificial intelligence (xAI). Since the actual mathematical processes of machine learning are too complex and sizeable for humans to productively investigate them directly, developers are trying to employ artificial intelligence for this task too, in work such as trying to model complex implementation by using a simpler and more comprehensible algorithm. ${ }^{*} 84$ Also, there are efforts to construct similar fictitious situations wherein the algorithm gives a different answer. To this end, some variables are ignored or changed (e.g., gender or age) while others

77 Germany: VwVfG § 39; France: Code des Relations entre le Public et l'Administration art L211-5; United Kingdom: House of Lords, $R v$ Secretary of State for the Home Department, ex parte Doody (1993) 3 All E.R. 92; European Union: TFEU art 296, para 2; On ECHR art 6 ECtHR Judgment 13616/88: Hentrich v France (1994), § 56; H Palmer Olsen et al., 'What's in the Box? The Legal Requirement of Explainability in Computationally Aided Decision-Making in Public Administration' (2019) 22. DOI: https://doi.org/10.2139/ssrn.3402974.

78 United States District Court, S.D. Texas, Houston Division: Hous. Fed'n of Teachers. - 251 F. Supp. 3d (2017) 1168. Nor has it been possible to explain algorithms that suggest that police patrols stop and check certain persons. For examples, see: S Valentine (n 13) 367, 372-373.

79 C Cath et al., 'Artificial Intelligence and the "Good Society”: The US, EU, and UK approach' (2017) 24 Science and Engineering Ethics 9. DOI: https://doi.org/10.2139/ssrn.2906249.

80 H Palmer Olsen et al. (n 77) 23-24. In Japan, for example, artificial intelligence is helping Members of Parliament prepare responses to citizens' memoranda. Harvard Ash Center (n 10) 8; K Lember (Master, Tartu) (n 2) 38. For more about this method, see: F Pasquale (n 54) 49 ff.

81 Decision of the Administrative Law Chamber of the Supreme Court 3-3-1-29-12, para 20. There is no reason to exclude the use of texts drafted with such a method if an official checks the draft substantially and carefully. See also: ibid; decision 3-17-1110/84, para 18, where the chamber explains that the reasoning for an administrative decision must not be limited to a mechanical copy of the norms.

82 Additional citations: M Herberger (n 17) 2827-2828; K Lember (Master, Tartu) (n 2); also GDPR, recital 71.

83 L Edwards and M Veale, 'Slave to the Algorithm: Why a Right to an Explanation Is Probably Not the Remedy You Are Looking for' (2017-2018) 16 Duke L. \& Tech. Rev. 18, 43, 56, 67. DOI: https://doi.org/10.31228/osf.io/97upg; E Berman (n 14) 1316-1317; W Hoffmann-Riem (n 28) 60. On restrictions to prison working methods, see: Tartu Circuit Court 3-16-418, para 12.

84 A Deeks (n 29) 1834; E Berman (n 14) 1317; L Edwards and M Veale (n 83) 61 ff; M Finck (n 20) 15. Among others, see: A Adadi and M Berrada, 'Peeking Inside the Black-Box: A Survey on Explainable Artificial Intelligence (XAI)' [2018] 6 IEEE Access 52138. DOI: https://doi.org/10.1109/access.2018.2870052 . 
are kept constant. This technique can be used to parse out the criteria instrumental to a given decision. ${ }^{*} 5$ But this still only takes us halfway: it is an explanation of the background of a statistical judgement, not a legal judgement itself. ${ }^{*} 86$ That may suffice if the administrative act is solving of a complex but mathematically solvable problem, such as predicting development or the likelihood of an event (e.g., the increase or decrease in the population of a protected species when a railway is built). ${ }^{*} 7$ Such judgements and predictions can be necessary, but the obligation of justification has a wider berth. In general, an administrative act may need an explanation of why legal provision $x$ is applied and not $y$, why a statutory provision is interpreted as $a$ and not $b$, what facts have been ascertained and why, why these facts are pertinent according to the relevant law, ${ }^{*} 88$ or why it is necessary to implement a certain measure (e.g., why should a dangerous structure be demolished instead of rebuilt?). All of these issues demand counter-arguments to the positions held by the parties to the proceeding that were not addressed in the decision. A robot cannot give adequate explanations for these thought operations because it does not perform such operations. ${ }^{*} 9$ If an administrative act requires a substantive legal justification, then the current level of information technology entails a need to place a human in the 'circuit'. 90

\subsection{Judicial review}

To ensure legality, it is recommendable to subject both private- and public-sector artificial-intelligence applications to multifaceted monitoring (documentation, auditing, certification, standardisation). ${ }^{*} 1$ This is necessary but cannot replace the judicial protection of persons who find that their rights may have been violated (Constitution $\$ 15$ (1), European Convention on Human Rights art. 6 and 13, Charter of Fundamental Rights of the European Union art. 47). If sufficient substantive and factual argumentation is given for administrative decisions made by means of an algorithm, there is no fundamental problem with judicial control. But difficulties arise in the absence of such argumentation. ${ }^{*} 92$

C. Coglianes and D. Lehr point out that courts tend to give deference to agencies when it comes to technically complex issues. ${ }^{*} 93$ But it's the algorithm that makes the decision complex! Implementing algorithms must not become a universal magic wand that frees the executive institution from judicial review for any decision. We can only talk of loosening control in situations wherein judges would, even without the use of artificial intelligence, defer for other reasons, such as the economic, technical, or medical complexity of the content or if the infringement of the rights of affected individuals is not excessively intense. Here, a complex administrative decision may include elements with different control intensity. ${ }^{*} 94$ Discussing this matter, E. Berman sees the opportunities for use of algorithms the more discretion an authority has. This position is somewhat confusing because it does not account for the breadth of discretion afforded by the law, or the significant influence of general principles and basic rights. Her ultimate conclusion is that control may be allowed to weaken where infringements are not very grievous and regulation is sparse and that it may disappear altogether in situations wherein no-one's rights are affected (e.g., deciding where to locate police

85 C Coglianese and D Lehr (n 14) 52; Deeks (n 29) 1836; T Wischmeyer (n 22) 61-62.

86 L Guggenberger (n 11) 849; K D Ashley, Artificial Intelligence and Legal Analytics: New Tools for Law Practice in the Digital Age (Cambridge University Press 2017) 3. DOI: https://doi.org/10.1017/9781316761380.

87 This may be important in determining bias, but bias is far from the only aspect to consider when one is reviewing an administrative decision.

88 The logical linking of so-called factual and legal reasoning using the example of restrictions to market trading: Decision of the Administrative Law Chamber of the Supreme Court 3-3-1-66-03, para 19.

89 K Lember (Master, Tartu) (n 2) 53.

90 See below for possible models, Section 4.

91 W Hofmann-Riem (n 28) $60 \mathrm{ff}$.

92 Unjustified, semi-automatic threat assessments used for parole decisions have been 'doomed' by the courts, which have stated that these 'mean nothing in the eyes of the court'. Tartu Circuit Court 1-13-8065, 26; Tartu County Court 1-13-7295, para 14; Criminal Chamber of the Supreme Court 1-09-14104, para 26-27.

93 C Coglianese and D Lehr (n 14) 44.

94 For example, when assessing the danger of a foreign repeat offender, the police do not have any room for uncontrolled evaluation if they plan to issue that person an expulsion order. Danger assessment is not only a statistical prognosis of a new offence but also a legal evaluation based on that prognosis - whether it matches the legislator's perception of a quantifiably undefined threshold. However, judicial review is limited in considering consequences (whether to issue an injunction and how long to refuse access), Decision of the Administrative Law Chamber of the Supreme Court 3-17-1545/18, para 28. See also: I Pilving, 'Kui range peab olema halduskohus?' (How Strict Must an Administrative Court Be?) [2019] 39 RiTo 61, 64ff. 
patrols). ${ }^{*} 95$ We can agree with this conclusion. As a general rule, administrative court proceedings retain control of rationality (including proportionality), which requires substantive administrative decisions that are at least monitored by humans as well as legal justification, with the exception of routine, mass decisions.

The problem of control cannot be solved simply by the administrative institution disclosing the content and raw data of the algorithm to the court. ${ }^{*} 96$ To analyse this material, the court would need its own IT knowledge or expert assistance. This is neither realistic from the angle of reasonable procedural resources nor in accordance with the constitutional roles given to the branches of government (Constitution §4). It would mean placing the primary responsibility for the compliance of an algorithm in the hands of the court where $\S \S 3$ and 14 of the Constitution place it in the hands of the executive power. There is no need to turn algorithms into direct subjects of judicial control. It is not necessarily important whether the data is distorted or has calibration errors or bias - these deficiencies may not affect the end result. It is also not the responsibility of the appellant to prove such deficiencies when challenging an algorithmic decision. And it is not a reasonable solution to compensate for the complexity of the algorithm with longer appeal times. Algorithmic administrative decisions must also obtain final, conclusive force within a reasonable amount of time. ${ }^{*} 97$ In court, it is important for administrative decisions taken by an algorithm to be legally justifiable. The executive institution must be convinced of the legality of its decision, and the process of forming such a conviction must be traceable without any special knowledge of computer science. This means using a so-called administrative Turing test, meaning that citizens and businesses must not detect any difference in whether a law-enforcement decision by the executive institution is made with the help of artificial intelligence or not. ${ }^{*} 98$ An institution using algorithms can implement the help of the algorithm for making a decision if it is able. If not, a representative of reasonable thought - an official - must step in.

\section{Conclusion: The division of labour between kratt and master}

Administrative decisions vary widely in terms of content, legal and factual framework, and decision-making process. Depending on the field and situation, rigid, standard solutions; generalisations; and simplifications may be allowed to a greater or lesser extent in administrative law. ${ }^{*} 99$ There are quite a few routine decisions that are subject to clear rules (e.g., in the areas of social benefits and taxes), and those can be trusted to computers working with non-learning or learning algorithms. ${ }^{*} 100$ It may also make sense to use self-learning algorithms in areas where there is wide latitude for governmental decisions and the decisionmaking requires a more non-judicial analysis (e.g., determining the positions for police patrols or modelling protected populations). ${ }^{* 101}$ But the important and complex decisions in society (e.g., where to build a railway or whether to build a nuclear power plant) are not routine and ought not be automated, at least not fully, because of a lack of appropriate learning data. These decisions need human judgement. ${ }^{* 102}$

In situations that fall between those two extremes, it is realistic to expect co-operation between the robot and the official, wherein the scope of each role may vary greatly, depending on the field and situation: ${ }^{* 103}$

More routine but not quite mechanical administrative decisions that are advantageous and lack negative side effects for the public and whose factual circumstances are comprehensible to an algorithm can be fully automated administrative decisions. However, the affected party must retain the right to request human review of the decision if desired. From a procedural point of view, it would be conceivable

95 C Coglianese and D Lehr (n 14) 1277, 1283.

96 M Schröder (n 36) 342. Where necessary, the court must have access to this information, irrespective of the interest of protecting business secrets. But the court may restrict the access of the other parties to information containing business secrets (Code of Administrative Court Procedure 88 (2)).

97 However, cf. J Cobbe (n 66) 8.

98 H Palmer Olsen et al. (n 77) 23.

99 T Wischmeyer (n 22) 34.

100 A Guckelberger (n 26) 386-387.

101 E Berman (n 14).

102 C Coglianese and D Lehr (n 14) 30; C Coglianese and D Lehr (n 8) 1214.

103 See also: A Guckelberger (n 26) 386. 
to provide a fully automatic administrative act as the initial act while allowing one month for the person to apply for a manual administrative act, for example. ${ }^{*} 104$

Administrative decisions of moderate complexity may require the administrative decision's approval by an official, but here we must avoid the 'rubber stamp' phenomenon. The official should first examine the arguments of the parties to the proceeding and the views of other authorities, assess the comprehensiveness and exhaustiveness of the facts on the basis of the investigative principle, and prepare a justification for the administrative act together with a thorough evaluation of his or her choices. As technology advances, there is reason to believe we will be able to use increasing assistance from machines in forming these justifications (to explain the aspects that tipped the scales or to prepare a draft justification or at least the more routine parts of it).

For factually or legally complex decisions, the weight of the decision must be borne by humans, at least until stronger artificial intelligence is developed, ${ }^{*} 105$ though learning algorithms may be used to evaluate individual elements of those decisions. Officials still should take direct statements from witnesses, communicate directly and humanely with the parties to the proceedings, and make principled and justified decisions.

With all of these variations, quality machine learning is particularly suitable for assisting officials in those areas of their job where they need to make predictions about circumstances or events on which humans lack certain knowledge as well (e.g., the likelihood of offences). But the legal decision (e.g., whether the prediction is sufficient to qualify as the justification for intervention) must be made by a human. ${ }^{*} 106$ Machine learning could also be implemented in very uncertain situations where a decision needs to be made but even officials would have trouble presenting rational justifications (e.g., a long-term environmental impact). ${ }^{*}{ }^{107}$ In any case, the implementation of machine learning in the performance of administrative tasks requires a sense of responsibility on the part of the institution as well as legal, statistical, and IT knowledge at least to the extent necessary to adequately outsource and oversee the development services. ${ }^{*} 108$

In conclusion, we are of the opinion that, at the current level of artificial intelligence, it is not possible to delegate atypical and complex administrative decisions to applications of it. Doing so is hindered both by the inability of the applications to conduct fair proceedings and explain the reasons and by the insufficiency of data. In conditions such as these, the delegation of a decision to an algorithm would be in conceptual conflict with the legality of administration and with procedural rules, along with the guarantee of judicial control. This is the actual state of things. The authors are not ambitious enough to predict whether implementation of 'science-fiction technology' available in the distant future could be in compliance with the law in effect at that time.

\footnotetext{
104 Code des Relations entre le Public et l'Administration, art L311-3-1 (2). See also K Lember's master's thesis (n 2) 40.

105 T Wischmeyer (n 22) 41.

106 Practical experience so far shows that officials play a decisive role in predictive decisions: T Rademacher (n 15) 378, 384.

107 Cf. A Vermeule, 'Rationally Arbitrary Decisions in Administrative Law' (2015) 44 The Journal of Legal Studies 475. DOI: https://doi.org/10.1086/676332.

108 C Coglianese and D Lehr (n 14) 30.
} 